\title{
Black Choke Disease of Warm Season Grasses Caused by Ephelis japonica in Japan and its Epiphytic Features
}

\author{
Takao TSUKIBOSHI ${ }^{1 *}$, Keiichi TAKAHASHI ${ }^{2}$, Ryuichi UEGAKI $^{3}$ and \\ Koya SUGAWARA ${ }^{4}$ \\ ${ }^{1}$ Livestock Research Team on Global Warming, National Institute of Livestock and Grassland \\ Science, National Agriculture and Food Research Organization (NARO) \\ (Nasushiobara, Tochigi 329-2793, Japan) \\ ${ }^{2}$ Food Safety Division, National Food Research Institute, NARO (Tsukuba, Ibaraki 305-8642, Japan) \\ ${ }^{3}$ Functional Biomolecules Research Team, National Institute of Livestock and Grassland Science, \\ NARO (Nasushiobara, Tochigi 329-2793, Japan) \\ ${ }^{4}$ Forage Production and Agro-Environment Research Team, National Institute of Livestock and \\ Grassland Science, NARO (Nasushiobara, Tochigi 329-2793, Japan)
}

\begin{abstract}
The causal fungus of black choke disease in various $\mathrm{C} 4$ warm season grasses was collected from places mainly in Ishigaki Island, the most southern region of Japan. The fungus was found on 19 species of 14 genera of C4-grasses such as Brachiaria, Chloris, Chrysopogon, Cynodon, Digitaria, Echinochloa, Eragrostis, Eriochloa, Imperata, Leptochloa, Miscanthus, Panicum, Paspalum, and Pennisetum, including turfgrasses and forage crops. The fungus colonizes flowering heads and makes them mummified in appearance with the panicles attaching to each other. The color of the mature stromata ranges from grayish-white to black. Leaf surfaces of some grasses are colonized by the fungus, producing white streaks of hyphae. Many colorless, needle-shaped conidia of 10-25 $\times 0.5-1 \mu \mathrm{m}$ are produced on infected tissues. The fungus was identified as Ephelis japonica based on the morphologies and molecular characteristics. Epiphytic features of E. japonica were examined using infected and uninfected Paspalum thunbergii clones from which the fungus was eradicated by treatment with a systemic fungicide. Hyphae colonized the surface of leaf primordia only in infected plants, a feature shared with some of the closely related Balansia spp. The potential for utilizing E. japonica to confer insect and disease resistance in turfs and forage crops was discussed.
\end{abstract}

Discipline: Plant disease

Additional key words: Balansia, C4-grass, epiphyte

\section{Introduction}

Black choke is a well-known disease of gramineous plants including rice causing sterile heads with black to gray stromata of mummified appearance ${ }^{32}$. The disease is common especially in India and China and called "Udbatta" and "Yi-Zhu-Xiang" disease of rice, respectively ${ }^{14,23}$. Many $\mathrm{C} 4$ warm season grasses have also been reported as hosts, such as Alloteropsis cimicina (L.) Stapf (summergrass) $^{7}$, Andropogon aciculatus ${ }^{22}$, Echinochloa crus-galli Beauv. (barnyard grass) ${ }^{13,31}$, Eragrostis nigra Nees ex Steud. ${ }^{7}$, Eragrostis tenuifolia (Rich.) Hochst. ex
Steud. (elastic grass) ${ }^{30}$, Isachne elegans Dalzell ex Hook. f. ${ }^{30}$, Leptochloa chinensis (L.) Nees (Chinese sprangletop $)^{15}$, Microstegium nudum (Trin.) Camus ${ }^{15}$, Paspalum orbiculare (Forst.) Hack (kodra millet) ${ }^{7}$, Pennisetum americanum (L.) Leeke (pearl millet) ${ }^{17}$, Setaria italica (L.) Beauv. (foxtail millet) ${ }^{13,31}$ and Sorghum vulgare L. (sorghum $)^{6}$ in India, Centotheca malabarica Merr., Chrysopogon aciculatus (Restz.) Trin., Digitaria adscendens (H.B.K.) Henr. (southern crabgrass), Echinochloa crus-galli subsp. submutica Honda, Lophatherum gracile Brongn., Microstegium ciliatum (Trin.) Camus, Miscanthus floridulus (Labill.) Warb. ex K. Schum. et Lauterb. (eulalia), Panicum repens L. (torpedo grass),

*Corresponding author: e-mail tuki@affrc.go.jp

Received 29 October 2007; accepted 11 January 2008. 
Paspalum orbiculare (kodra millet), Pennisetum alopecuroides (L.) Spreng. (purple fountain grass) and Saccharum formosanum (Stapf) Ohwi var. pollinioides (Rendle) Ohwi in Taiwan ${ }^{20}$, Eulaliopsis binata (Retz.) Hubb. (sabaigrass) in China ${ }^{12}$, Eriochloa polystachya Kunth in Puerto-Rico ${ }^{33}$, and Pennisetum alopecuroides (purple fountain grass) in $\mathrm{USA}^{19}$, in addition to rice. In Japan, although the disease has never been reported on rice, it first occurred on Miscanthus tinctorius Hack. (eulalia) and Paspalum thunbergii Kunth:Steud. (knotgrass) in $1904^{5}$. Setaria italica (foxtail millet) was also reported as the host of the disease in $1930^{8}$. Nishihara, N., reported the occurrence on Paspalum thunbergii (knotgrass), Pennisetum alopecuroides, Eragrostis ferruginea (Thunb.) Beauv. (lovegrass), and Sporobolus fertilis (Steud.) Clayton (smutgrass) mainly in Kyushu district in 1960 (unpublished data). We have already reported the occurrence of the disease on 19 species of warm season grasses tested in this study ${ }^{2,9,26,27}$.

The pathogen of black choke disease has been identified as Ephelis oryzae Sydow, Balansia andropogonis Sydow, Ephelis sp. or others of the Clavicipitaceae, Ascomycota, and the species name is somehow confused. The objective of this study is to identify the fungus based on the morphologies and molecular characteristics of the isolates collected from 19 species of C4 warm season grasses. In addition, because the fungus infects plants systematically with a sign of white streaks of hyphae on the leaves, the study was made to observe the epiphytic features of the fungus using the pathogen-free plants treated with a permeable systematic fungicide.

\section{Materials and methods}

Samples of warm season grasses showing black choke and/or leaf streak symptoms were collected from Ishigaki Islands in Okinawa Prefecture, the southern most part of Japan and Nasushiobara in Tochigi Prefecture, the central part of Japan in February and July 1998, respectively ${ }^{27}$. Twenty samples from 19 species of 14 genera in four families of grasses such as Eragrostis ferruginea and Leptochloa paniceae (Retz.) Ohwi of Eragrostideae, Chloris barbata Swartz, Chloris divaricata R. Br., Cynodon dactylon (L.) Pers. and Cynodon pletostachyrus (K. Schm.) Pilger of Cynodontidaea, Brachiaria mutica (Forsk.) Stapf, Digitaria eriantha Steud., Digitaria violascens Link, Echinochloa crus-galli, Eriochloa procera C. H. Hubb., Panicum repens, Paspalum orbiculare, Paspalum thunbergii, Paspalum urvillei Steud. and Pennisetum alopeculoides of Paniceae, and Chrysopogon aciculatus, Imperata cylindrica (L). Beauv. var. koenigii (Retz.) Durand et Schinz and Miscanthus sp. of
Andropogoneae were collected. The samples of the infected heads or leaves were kept in a moist chamber at $25^{\circ} \mathrm{C}$ under a near-ultraviolet light $(12 \mathrm{hr} / 12 \mathrm{hr}$ photoperiod) to produce conidia on the diseased samples. The produced mass of conidia was spread on water agar $(1.5 \%$ agarose, WA) and a single germinated conidium was isolated and incubated on acid potato dextrose agar (PDA, $\mathrm{pH}$ 5.0) for each sample. Twenty isolates (Ep-1 to -20) were obtained and preserved on PDA in slants at $20^{\circ} \mathrm{C}$ and deposited to MAFF (Ministry of Agriculture, Forestry and Fisheries of Japan) microorganism genebank with MAFF isolate numbers of 306575 to 306588 and 306623 to 306625. The obtained isolates are shown in Table 1.

Morphological characteristics of conidia of the isolates were taken from the conidial mass produced on the diseased tissues or on the cultures with PDA under the near-ultraviolet light as described above. Produced conidia were stained with DAPI (4', 6-diamino-2-phenylindole, WAKO) for the observation under a fluorescent microscopy. Mycelial growth of the isolates were estimated on PDA in dark at temperatures that ranged from 15 to $35^{\circ} \mathrm{C}$.

The total gDNA of each isolate was obtained from the fungal body through phenol-chloroform extraction as described before ${ }^{28}$. PCR amplification was performed using the primers ITS1 (forward) and ITS4 (reverse) specific for the ribosomal DNA (rDNA)- Internal transcribed spacer (ITS) regions (ITS1+5.8S rDNA+ITS2) ${ }^{34}$ with the gDNA as a template. PCR conditions were the same as described before ${ }^{28}$. Restriction fragment length polymorphism (RFLP) of the PCR products were analyzed by treating the products with a restriction enzyme, Mbo I (Takara Bio Inc.) according to the manufacturer's instruction.

To observe the epiphytic features of the black choke pathogen in the infected plants, the pathogen-free plants were obtained by treating infected plants with permeable systematic fungicide as described before ${ }^{29}$. Infected plants of Paspalum thunbergii (knotgrass) collected in Nasushiobara, Tochigi were separated into two tillers and one half was rinsed in a $1 \%$ trifoline $\left(\mathrm{Saprol}^{\mathrm{R}}\right.$ emulsion, Kumiai Chemical Industry Co., Ltd.) solution overnight. The surviving plants were checked for the presence of the fungus and the symptomless ones were used for the black choke-free clone for the following experiments. Leaf primordia of the black choke-infected and-free plants were excised and observed under a microscopy. Surfaces of the leaves were observed by scanning electronic microscopy (SEM, Hitachi S-800) after fixation by the method of Koga et al. (1999) $)^{9}$. 


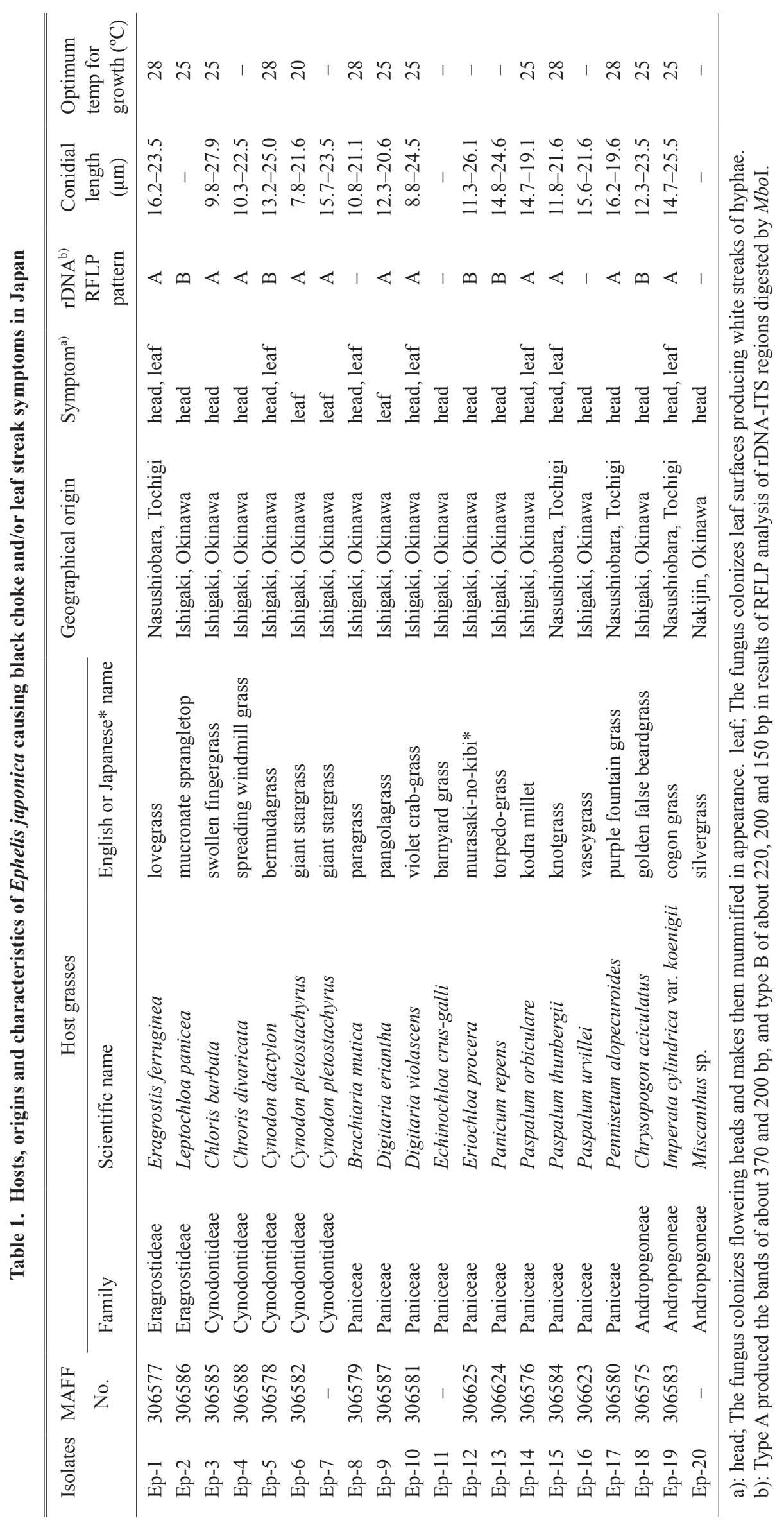




\section{Results}

\section{Symptom}

In black choke symptom on heads, the fungus colonizes flowering heads and mycelia enclose the panicles, preventing expansion and resulting in the mummified appearance of the infected head. The colors of the mature fungal stromata range from grayish-white to black according to the maturity and kinds of host grasses (Fig. 1). Sclerotia-like structures, grayish black and 1-2 $\mathrm{mm}$ in diameter were sometimes produced in the infected heads. In leaves, white dense layers of hyphae colonize the adaxial leaf surfaces and sheaths epiphytically producing white streaks symptoms. Since headings are rare in Cynodon pletostachyrus (giant stargrass) and Digitaria eriantha (pangolagrass) in Ishigaki Island, only leaf streak symptom was observed in the hosts. Both head and leaf symptoms were observed in Eragrostis ferruginea, Cynodon dactylon (bermudagrass), Brachiaria mutica (paragrass), Digitaria violascens, Paspalum orbiculare, Paspalum thunbergii, and Imperata cylindrica var. koenigii (Table 1).

\section{Causal fungus}

Colonies on PDA were first white cottony and then turned yellowish or brownish with laciniate margins (Fig. 2A). Mycelia grew at temperatures of 15 to $30^{\circ} \mathrm{C}$ and never at $35^{\circ} \mathrm{C}$. Optimum temperature for growth ranged 20 to $28^{\circ} \mathrm{C}$ (mostly $25-28^{\circ} \mathrm{C}$ ) according to the host grass but there were no relationships between optimum temperatures and their geographical origin (Table 1). On the stromata of diseased heads and leaves, palisades of conidiophores are produced (Fig. 2B). They terminate in narrow phialides producing many conidia on the tips. Conidia are colorless, needle-shaped, non-septate, 8.8-27.9 × 0.9$2.7 \mu \mathrm{m}$ and containing one nucleus per conidium through observation under the fluorescent microscopy after staining with DAPI (Fig. 2C, D). As shown in Table 1, there was no relationship between conidial length and geographical origins or hosts of the fungal isolates. No teleomorphs of the fungus have been observed in nature.

\section{PCR-RFLP analysis}

In results of PCR-RFLP analysis, the tested isolates were classified into 2 types. Type A produced the bands of approximately 370 and $200 \mathrm{bp}$, whereas type B produced the bands of approximately 220, 200 and $150 \mathrm{bp}$. Type A was found both in Tochigi and Okinawa, but type B was found only in Okinawa (Ishigaki Island), the most southern region of Japan (Table 1).

\section{Epiphytic features in the infected plants}

In the black choke-infected knotgrass, hyphae of the fungus colonized the surface and basal part of leaf primordia and surrounding tissues (Fig. 3A). However, the leaf primordia appeared intact without visual damages by the hyphae. On the other hand, no hyphal extensions were observed in the tissues of the black choke-free plants. By scanning electron microscopy (SEM), it was observed that many strands of hyphae with conidial masses extended epiphytically on the surface of the leaves of black chokeinfected plants (Fig. 3B). No invasions of the hyphae through stomata or cuticle layers of the leaves were observed.

\section{Discussion}

Based on conidial morphology, all isolates from the collected plants were distinctly assigned to the genus Ephelis, the anamorph of Balansia (Clavicipitaceae). The scientific names of the fungus causing black choke disease on grasses including rice are now somehow confused and the species name, Ephelis oryzae Sydow (= Balansia oryzae-sativae Hashioka), Ephelis pallida Pat. (= Balansia andropogonis Sydow), Ephelis japonica Henn., Ephelis sp., and Balansia discoidea Henn. (no anamorph name), have been adopted by many authors. Diehl $(1950)^{4}$ indicated that E. pallida is a doubtful name because there are no descriptions of it. The morphologies of the isolates we collected in Japan coincided with the description of $E$. oryzae $^{1}$ and E. japonica ${ }^{5}$. Diehl $(1950)^{4}$ thought that $E$. japonica may be the same as E. oryzae, because there are no differences between morphologies of E. oryzae and $E$. japonica in their original descriptions. However, because E. japonica was described in 1904, before the description of E. oryzae in $1913^{22}$, we adopted the name, E. japonica, based on the priority since no teleomorphs have been observed in nature. The original description of E. japonica is as follows.

\section{Ephelis japonica Hennings (Hennings 1904) ${ }^{5}$}

Stromatibus inflorescentiicolis eas deformantibus, irregulariter pulvinatis effusis, rugosis, sclerotoideis, atris, ca. 2-4 mm diam.; peritheciis subcupulato-apertis, ca 1-2 $\mathrm{mm}$ diam.; conidiophoris repetito-dichotomis, hyalinis, ca. 2-3 $\mu$ crassis, conidiis filiforme-fusoideis, utrinque acutis, guutulatis, $20-30 \times 0.7-1 \mu$.

The genus Ephelis has already been phylogenetically analyzed based on the sequences of rDNA-ITS regions and the mating loci with other Clavicipitaceae fungi ${ }^{10,35-37}$. We elucidated that there existed two types in E. japonica isolates in results of PCR-RFLP. Tanaka et al. $(2001)^{25}$ 

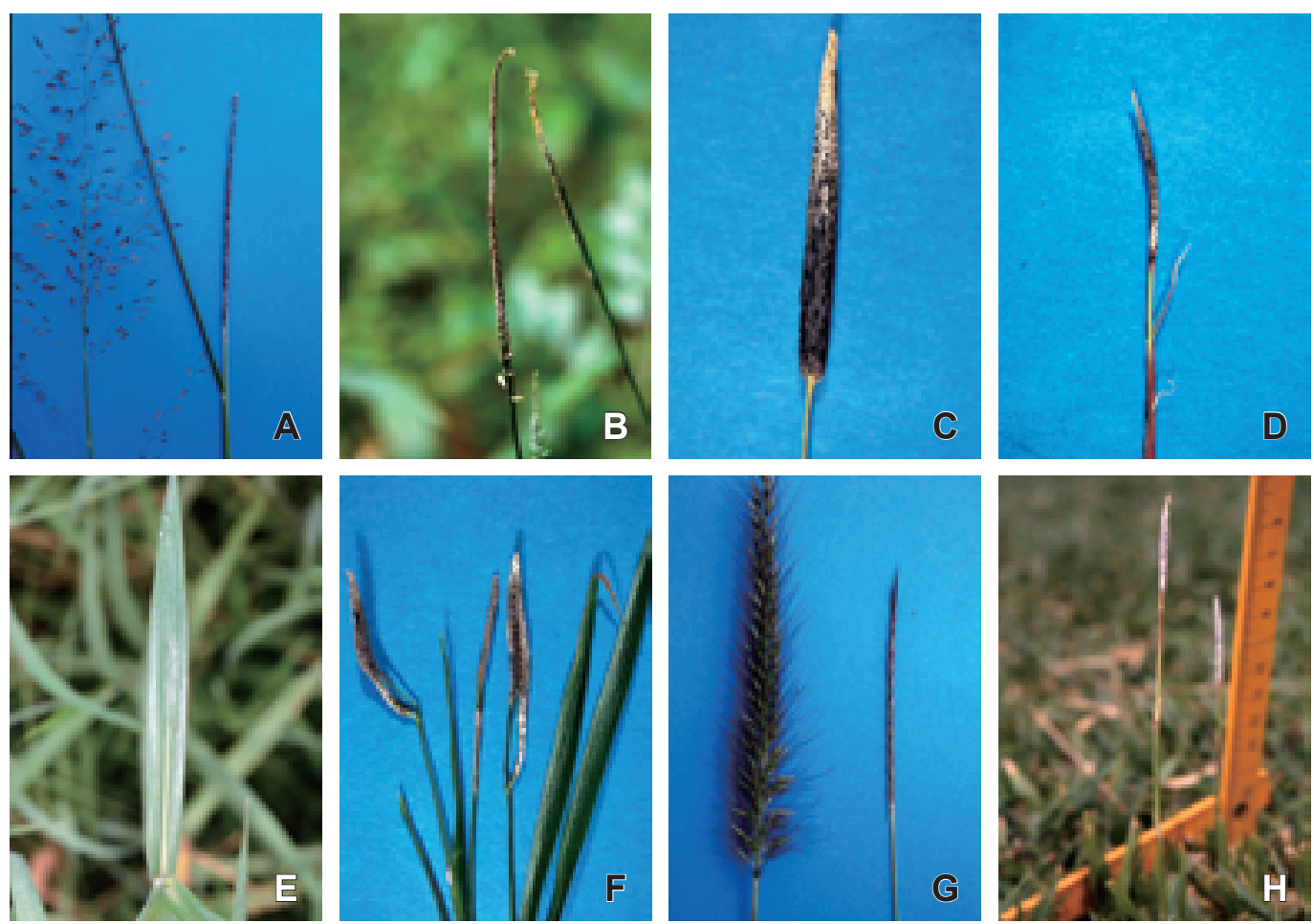

Fig. 1. Symptoms of black choke disease in $\mathrm{C} 4$ warm season grasses

A: Eragrostis ferruginea (healthy and infected heads), B: Leptochloa panicea (infected heads), C: Chloris barbata (infected head), D: Cynodon dactylon (infected head), E: Brachiaria mutica (infected leaf), F: Paspalum thunbergii (infected heads and leaves), G: Pennisetum alopecuroides (healthy and infected heads), H: Chrysopogon aciculatus (infected heads).
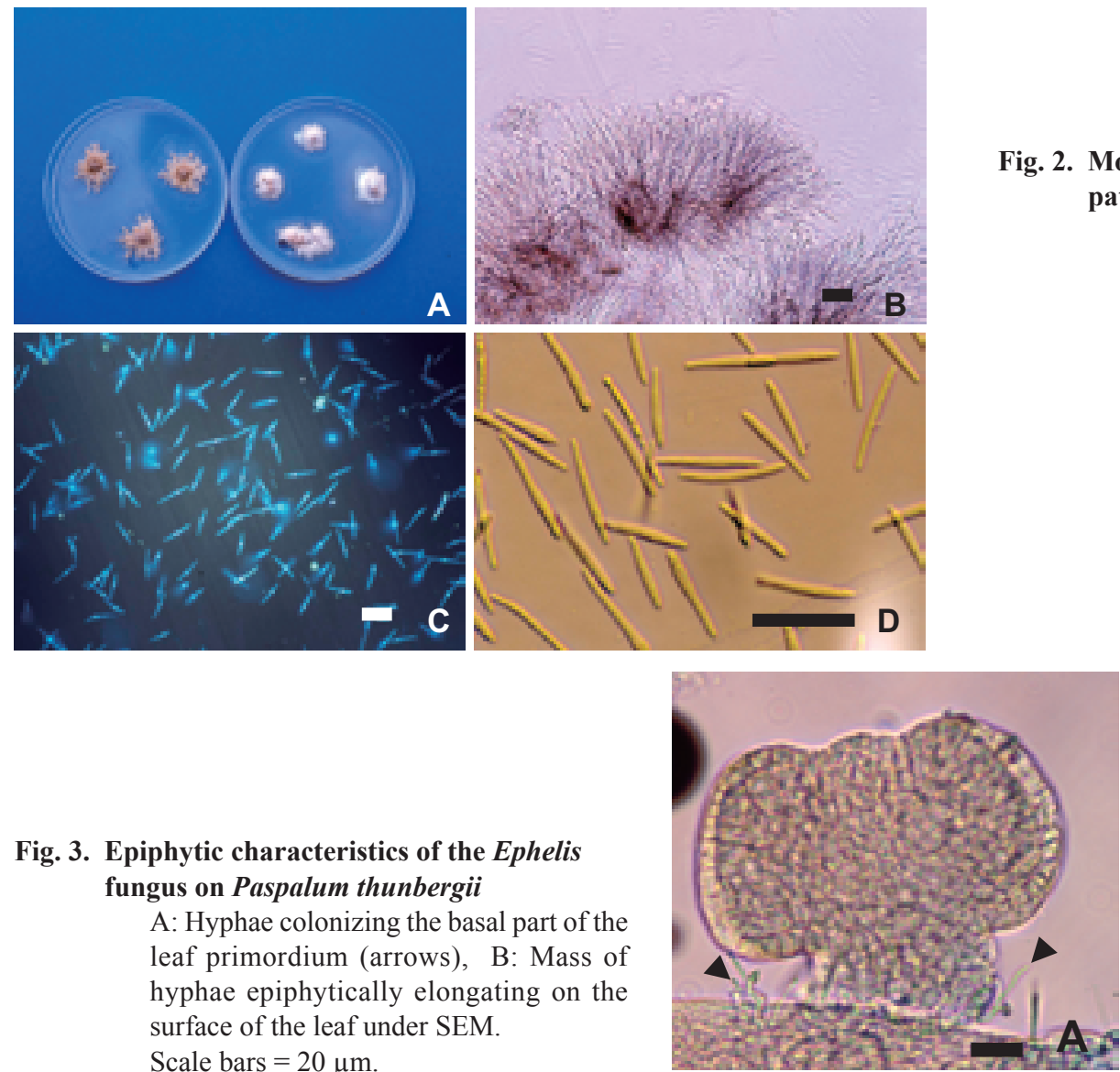

Fig. 3. Epiphytic characteristics of the Ephelis fungus on Paspalum thunbergii

A: Hyphae colonizing the basal part of the leaf primordium (arrows), B: Mass of hyphae epiphytically elongating on the surface of the leaf under SEM.

Scale bars $=20 \mu \mathrm{m}$.
Fig. 2. Morphologies of Ephelis fungus, the pathogen of black choke disease

A: Colonies on PDA, B: Stromata with palisades of conidiophores that terminate in narrow phialides producing many conidia on the tips, C: Conidia containing a nucleus under the fluorescent microscopy, D: needle-shaped and non-septate conidia from Paspalum urvillei. Scale bars $=20 \mu \mathrm{m}$.

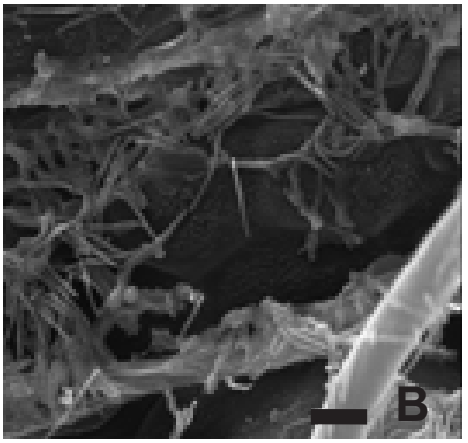


have already classified $E$. japonica isolates into two subgroups such as subgroup 1 including $B$. andropogonis and subgroup 2 including $B$. discoidea in results of phylogenetic studies based on rDNA-ITS sequences using our $E$. japonica isolates. Subgroup 2 perfectly includes Type A and E. oryzae, and subgroup 1 includes Type B of this study. The two groups are necessarily different species based on the phylogenetic study, even if there are no differences between the morphologies of anamorph of the two groups. Therefore, E. japonica including E. oryzae should be transferred to $B$. andropogonis or B. discoidea after confirming the morphologies of teleomorphs in nature. The isolates of type B (B. andropogonis-group) were found only in Okinawa Prefecture, the most southern area, whereas type A (B. discoidea-group) was also found in Tochigi Prefecture, the central area of Japan. It may indicate the distribution of the two types of E. japonica in Japan.

Although black choke disease has been described only on the head symptom, we first described leaf colonization showing white streaks by the causal fungus, $E$. japonica. The characteristics of the fungus inhabiting the leaf surface are important to show its epiphytic and systematic nature $^{2}$. The hyphae elongating around the base of leaf primordia also support that the fungus should be an epiphyte. Reddy et al. (1998) ${ }^{18}$ described B. andropogonis and B. discoidea as epibiotic, Asian and epibiotic, American species, respectively, based on the phylogenetic study on rDNA-ITS. They separated these species from endophytic Balansia, such as B. obtecta or B. calviceps. This coincides with our observation on the epiphytic features of E. japonica.

E. japonica has already been reported to confer insect resistance to the infected plants. Takahashi et al. $(2001)^{24}$ found that an armyworm, Mythimna separata (Walker), preferred E. japonica-free Digitaria eriantha (paragrass) to the infected ones and a grasshopper, Aiolopus thalassinus tamulus (Fabricius), preferred E. japonica-free Cynodon pletostachyrus (giant stargrass). Uegaki et al. $(2000)^{29}$ also reported the inhibitory effects of the fungus against rice grasshopper, Oxya yezoensis Shiraki on Paspalum thunbergii (knotgrass). B. cyperi Edg. and B. pilulaeformis (Burk. \& Curt.) Diehl ${ }^{3}$ are also known as an epiphytic species inhabiting Cyperus vires Michx. (green sedge) of Cyperaceae and Chasmanthium laxum (L.) Yates (slender woodoats), respectively. Their hyphae grow around the meristem and leaf primordia of the plants ${ }^{11} . B$. cyperi is reported to confer fungitoxic effects to the infected plants against Fusarium and Rhizoctonia ${ }^{21}$ producing ergobalansine, ergot-type peptide alkaloid ${ }^{16}$. Therefore, some epiphytic species of Ephelis or Balansia are thought to confer resistance to diseases, pests or envi- ronmental stress in nature as a symbiont, the same as $E$. japonica.

The results of our study indicate that the Ephelis fungus is potentially suited as a symbiont of C4-grasses for biological control of diseases and pests similar to Neotyphodium as endophyte of C3-grasses. It should be possible to utilize the fungus for controlling pests or diseases in the original hosts, bermudagrass (used as turf grass), paragrass and giant stargrass (both used as forage crops). However, since no inoculation methods of the fungus have been developed, further studies are necessary for the utilization of the Ephelis fungus as a symbiont of C4-grasses.

\section{References}

1. Booth, C. (1979) Balansia oryzae-sativae [Descriptions of fungi and bacteria]. IMI descriptions of fungi and bacteria, 64, sheet 640, CAB International, Wallingford, UK.

2. Christensen, M. J. et al. (2000) Occurrence of an Ephelis fungus on Ishigaki Island and observations on its epiphytic association with host grasses. JIRCAS J., 8, 49-59.

3. Clay, K. \& Frentz, I. C. (1993) Balansia pilulaeformis, an epiphytic species. Mycologia, 85, 527-534.

4. Diehl, W. W. (1950) Balansia and the Balansiae in America. Agriculture Monograph No.4, USDA, Washington, D. C., pp.82

5. Hennings, P. (1904) Einige neue Pilze aus Japan II. Hedwigia, 43, 150-153.

6. Hiremath, P. C. et al. (1982) Sorghum an additional host for Ephelis oryzae. Indian Phytopathol., 35, 547-548.

7. Indrasenan, G. \& Mammen, M. K. (1983) New graminaceous weed hosts of Ephelis oryzae Syd. in Wynad. Agric. Res. J. Kerala, 21, 92-94.

8. Itsumi, T. (1930) Black choke disease on foxtail millet. Nihon Shokubutsu Byouri Gakkaihou (Ann. Phytopathol. Soc. Jpn.), 2, 294 [In Japanese].

9. Koga, H. et al. (1999) Occurrence of black choke in Eragrostis ferruginea (Thunb.) Beauv. and Pennisetum alopecuroides (L.) Spreng. caused by Ephelis sp. in Japan. Bull. RIAR Ishikawa Agric. Coll., 6, 45-52.

10. Kuldau, G. A. et al. (1997) Molecular systematics of Clavicipitaceae supporting monophyly of genus Epichloë and form genus Ephelis. Mycologia, 89, 431-441.

11. Leuchtmann, A. \& Clay, K. (1988) Atkinsonella hypoxylon and Balansia cyperi, epiphytic members of the Balansiae. Mycologia, 80, 192-199.

12. Li, H. L. et al. (1992) Ephelis sp. disease on Eulaliopsis binata. Plant Prot., 18, 47.

13. Manomonhan D. et al. (2000) New weed host of Ephelis oryzae, the causal organism of Udbatta disease of rice from Kerala. Indian Phytopathol., 53, 234.

14. Mohanty, N. N. (1964) Studies on "Udbatta" disease on rice. Indian Phytopathol., 17, 308-316.

15. Mohanty, N. N. (1976) Ephelis on two new grass hosts. Indian Phytopathol., 28, 537-539.

16. Powell, R. G. et al. (1990) Ergobalansine, a new ergot- 
type peptide alkaloid isolated from Cenchrus echinatus (sandbur grass) infected with Balansia obtecta, and produced in liquid cultures of B. obtecta and Balansia cyperi. J. Nat. Prod., 53, 1272-1279.

17. Reddy, H. R. \& Channamma, K. A. L. (1976) Occurrence of Ephelis oryzae Syd. on pearl millet. Curr. Sci., 45, 394.

18. Reddy, P. V. et al. (1998) An examination of molecular phylogeny and morphology of the grass endophyte Balansia claviceps and similar species. Mycologia, 90, 108-117.

19. Roberts, E. L. \& White, Jr, J. F. (2006) Black choke disease caused by an Ephelis sp. on purple fountain grass in Maryland. Plant Dis., 90, 112.

20. Sawada, K. (1944) Descriptive catalogue of Taiwan (Formosan) fungi, part 10. Rep. Govt. Res. Inst. Formosa, 87, 6-8.

21. Stovall M. E. \& Clay, K. (1991) Fungitoxic effects of Balansia cyperi. Mycologia, 83, 288-295.

22. Sydow, H. (1913) Beiträge zur Kenntnis der Pilzflora des südlichen Ostindiens II. Annu. Mycol. Berl., 11, 489.

23. Tai, F. L. \& Siang, W. N. (1948) "I-Chu-Hsiang" disease of rice caused by Ephelis oryzae Sydow in Yunnan. Acta Agric., 1, 125-131.

24. Takahashi, K. et al. (2001) Inhibitory effect of an epiphytic fungus, Ephelis japonica, on the feeding of Mythimna (Pseudaletia) separata (Lepidoptera: Noctuidae) and Aiolopus thalassinus tamulus (Orthoptera: Acrididae). JIRCAS J., 9, 17-21.

25. Tanaka, E. et al. (2001) Phylogenetic studies of Ephelis species from various locations and hosts in Asia. Mycol. Res., 105, 811-817.

26. Tsukiboshi, T. et al. (1997) First report of black choke disease of 13 species of warm-season grasses caused by Ephelis sp. in Japan. Nihon Shokubutsu Byouri Gakkaihou (Ann. Phytopathol. Soc. Jpn.), 63, 496 [In Japanese].
27. Tsukiboshi, T. (1999) Exploration and collection of Ephelis sp. causing black choke of warm season grasses. Biseibutsu Idenshigen Tansaku Syushu Chousa Houkokusho (Ann. Rep. Explor. Introd. Microb. Gen. Res.), 11, 1-6 [In Japanese with English summary].

28. Tsukiboshi, T. et al. (2005) Cochliobolus heveicola sp. nov. (Bipolaris heveae) causes brown stripe of Bermudagrass and Zoysia grass. Mycoscience, 46, $17-21$.

29. Uegaki, R. et al. (2000) Feeding evasion for rice grasshopper (Oxya yezoensis) of Ephelis-endophyte infected knotgrass (Paspalum thunbergii). Grassl. Sci., 46, 74-76 [In Japanese].

30. Venkatakrishniah, N. S. (1946) Ephelis on two new hosts. Curr. Sci., 15, 260-261.

31. Venkatakrishniah, N. S. (1952) Ephelis on two new hosts. Phytopathology, 42, 634-636.

32. Webster, R. K. \& Gunnell, P. S. (1992) Compendium of rice diseases. APS Press, Minnesota, USA, pp.86.

33. Weiss, F. A. (1945) Check list revision. U. S. Bur. Plant Ind., Soils, Agric. Eng. Plant Dis. Report., 27, 175-184.

34. White, T. J. et al. (1990) Amplification and direct sequencing of fungal ribosomal RNA genes for phylogenetics. In PCR protocols: a guide to methods and applications, eds. Gelfand, M., Sninsky, D. \& White, T., Academic Press, California, USA, 315-322.

35. Yokoyama, E. et al. (2004) Development of a PCR-based mating type assay for Clavicipitaceae. FEMS Microbiol. Lett., 237, 205-121.

36. Yokoyama, E. et al. (2006) Phylogenetic and structural analyses of mating-type loci in Clavicipitaceae. FEMS Microbiol. Lett., 264, 182-191.

37. Zhou, Y. L. et al. (2003) PCR-based specific detection of Ustilaginoidea virens and Ephelis japonica. J. Phytopathol., 151, 513-518. 